\title{
RECHTERLIJK DWALING DALAM TINJAUAN FIKIH JINAYAH DAN HUKUM POSITIF
}

\author{
Afidah Wahyuni \\ Fakultas Syariah dan Hukum UIN Jakarta \\ Jl. Ir. H. Juanda 95, Ciputat Jakarta \\ E-mail: afidah.wahyuni@uinjkt.ac.id
}

\begin{abstract}
Rechterlijk Dwaling in Jurisprudence Review of Jinayah and Positive Law. This study shows that jinayah Islamic jurisprudence and criminal law determine how to overcome rechterlijk dwaling by conducting a review of the decision. There are same principals why both rechterlijk dwaling and jinayah islamic jurisprudence exist. This comes weather from internal and external of the judge. Similarly, the effect and the legal consequences of rechterlijk dwaling, according to both criminal law and jinayah islamic jurisprudence.
\end{abstract}

Keywords: negligence, verification, justice, rehabilitation

\begin{abstract}
Abstrak. Rechterlijk Dwaling dalam Tinjauan Fikih Jinayah dan Hukum Positif. Studi ini menunjukkan, fikih jinayah Islam dan hukum pidana menentukan bahwa cara yang ditempuh dalam mengatasi rechterlijk dwaling adalah dengan mengadakan peninjauan kembali terhadap putusannya. Penyebab adanya rechterlijk dwaling dalam fikih jinayah Islam dan hukum pidana pada prinsipnya sama, baik dari sisi hakim sendiri maupun dari faktor di luar hakim. Demikian pula pengaruh dan akibat hukum dari rechterlijk dwaling, baik menurut hukum pidana maupun fikih jinayah Islam.
\end{abstract}

Kata kunci: kealpaan, pembuktian, keadilan, rehabilitasi

\section{Pendahuluan}

Putusan yang sudah sampai pada tingkat kekuasaan kehakiman tertinggi patut diterima kebenarannya, walaupun tidak mutlak. Kita patut tetap berpijak pada kenyataan bahwa manusia diciptakan Tuhan adalah dhaif dan tidak sempurna. Tidak luput dari kemungkinan melakukan kekhilafan dan kesalahan.

Keberadaan Mahkamah Agung tidak lain maksudnya memberi kesempatan bagi pencari keadilan mencari dan memperoleh keadilan semaksimal mungkin. Keadilan yang mutlak memang sulit diwujudkan, namun putusan yang diharapkan setidak-tidaknya mendekati keadilan. Karena keadilan yang sempurna adalah di tangan Allah Swt. sedangkan perintah berbuat adil hanyalah semampu yang ada pada manusia dan Allahlah yang Maha Mengetahui.

Bilamana Mahkamah Agung sudah memberi putusan akhir, secara formal putusan tertinggi itu tidak dapat diganggu gugat lagi. Akan tetapi sebagaimana dikemukakan, hakim adalah manusia, ia tidak luput dari

Naskah diterima: 3 Januari 2015, direvisi: 6 Februari 2015, disetujui untuk terbit: 14 Maret 2015. kesalahan. Katakanlah putusan dari Mahkamah Agung itu mengandung ketidakbenaran, serta tidak diragukan lagi dari bukti-bukti, terkadang seorang hakim terbentur dengan putusan yang keliru dan tidak adil atau bisa sama sekali meleset dari putusan yang dituduhkan.

Dalam hal ini dikemukakan peraturan dari Mahkamah Agung No. 1 tahun 1980 yang dikenal dengan "Peninjauan Kembali putusan yang telah mempunyai kekuatan hukum yang tetap". Upaya mencari keadilan ke tingkat yang tinggi, sebagaimana dalam hukum positif,dalam hukum Islampun ada dan pernah digambarkan serta dipraktikkan oleh Rasulullah Saw.

\section{Faktor-faktor Penyebab Recterlijk Dwaling ${ }^{1}$}

Sehubungan dengan hal ini, Soerjono Soekanto, berpendapat ada beberapa faktor, yaitu: (1) Faktor

Rechterlijk adalah segala sesuatu yang berhubungan dengan hakim atau pelaksananya. Dwaling adalah terjadi bila seseorang tidak mengetahui bahwa tindakannya melawan hukum, di mana orang itu secara wajar sebelumnya tidak menduga bahwa tindakannya melawan hukum tanpa hak. Jadi, Rechterlijk Dwaling adalah segala sesuatu yang berhubungan dengan pelaksanaan hukum oleh hakim (vonis), di mana dalam pelaksanaan hukum itu hakim tidak menduga dan tidak mengetahui bahwa tindakannya melawan hukum. 
hukum sendiri, yang membatasi pada Undang-undang saja; (2) Faktor penegak hukum, yaitu pihak yang membentuk maupun yang menerapkan hukum; (3) Faktor masyarakat, yaitu lingkungan di mana hukum itu berlaku; (4) Faktor kebudayaan, yaitu sebagai hasil karya, cipta dan rasa yang didasarkan pada karsa manusia dalam pergaulan hidup. ${ }^{2}$

Adapun penyebab kealpaan putusan hakim dapat diklasifikasikan menjadi dua faktor: (1) Faktor internal, yaitu dari hakim sendiri dan (2) faktor eksternal, yaitu di luar putusan hakim.

Pertama, faktor internal. Sering kali dijumpai dan terdengar seorang hakim dalam menjalankan tugasnya masih berat sebelah, akan tetapi mungkin secara jujur keadaan itu merupakan hal yang luar biasa. Karena citra hakim, baru akan terpelihara dengan baik apabila dilandasi dengan kejujuran. Seorang hakim yang benarbenar jujur dalam tugasnya adalah mereka yang menjadi hakim karena panggilan jiwanya dan bukan hanya sekadar untuk menghindarkan diri dari ketiadaan kerja atau hanya membalas dendam ataupun hanya ambisi. Hal ini tidak dibenarkan oleh ajaran Islam, sebagaimana sabda Rasulullah:

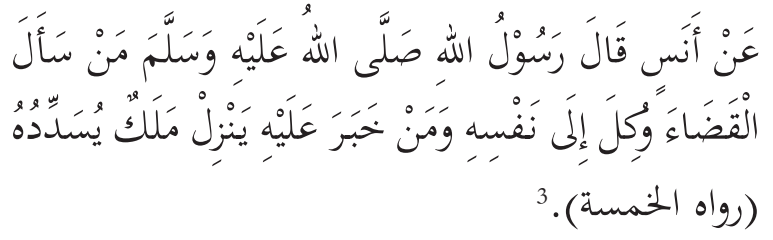

Dari Anas Ra., Rasulullah Saw. bersabda, "Barangsiapa yang minta jabatan peradilan maka diserahkan secara penuh segala urusan itu kepada dirinya sendiri (tanpa ada lindungan dari Allah) dan barang siapa yang diangkat dalam jabatan itu, maka akan turun malaikat untuk membimbingnya. (Hr. Khamsah)

Hakim sebagai penegak hukum dalam lingkungan kehakiman (yudikatif) juga mempunyai kebebasan yang mutlak. Kebebasan dalam melaksanakan wewenang yudisial yang dimaksud di atas, adalah untuk menegakkan hukum dan keadilan yang bebas dari campur tangan pihak kekuasaan negara, dan kebebasan dari rekomendasi yang datangnya dari pihak ekstra yudisial, kecuali dalam hal yang diizinkan oleh Undang-Undang. ${ }^{4}$

Sementara kebebasan dan ketaatan terhadap aturan hukum, maka pernah terjadi pada masa pemerintahan khalifah Ali bin Abi Thalib adalah peristiwanya sebagai berikut:

${ }^{2}$ Soerjono Soekanto, Faktor-faktor yang Mempengaruhi Penegakan Hukum, (Jakarta: Rajawali, 1986), h. 2.

${ }^{3}$ Al-Syawkânî, Nayl al-Awthâr, (Mesir: Mustafa Al Babi Al Halabi, tth.), h. 214.

${ }^{4}$ Harief Harahap, Himpunan Peraturan dan Perundang-undangan RI, (Jakarta: Pradya Paramita, 1973), h. 60.
Sebelum Ali bin Abi Thalib menjadi khalifah, pernah kehilangan baju besinya. Setelah menjadi khalifah, baju besi yang hilang itu diketahui berada di tangan orang Yahudi. Lalu Ali ra. Berkata kepada orang Yahudi tersebut katanya, "Baju yang ada padamu itu adalah milik saya”. Lalu orang Yahudi tersebut menjawab, "Bukan, ini milik saya sejak dulu". Dengan adanya saling mempertahankan itu, maka persoalan ini memerlukan penyelesaian di pengadilan. Lalu perkara tadi diperiksa oleh hakim yang diangkat oleh Ali bin Abi Thalib sendiri, yaitu bernama Syuraih. Akhirnya, dari hasil pemeriksaan tersebut, hakim menjatuhkan putusannya dengan mengatakan, "Karena Amirul Mu’minin sebagai pendakwa tidak dapat membuktikan dengan pengakuan dua orang saksi yang sah, yang dapat memperkuat tuntutannya itu, maka dengan ini saya putuskan, bahwa baju besi itu adalah hak milik yang membawa atau yang memegang barang itu, sekarang, yaitu orang Yahudi". 5

Sikap yang dicontohkan oleh hakim tersebut sejatinya berkaitan erat dengan mental dari hakim sendiri yang teguh walaupun ada tekanan yang sifatnya mempengaruhi putusannya. Oleh karena itu, dalam Pasal 14 ayat (1) Undang-Undang No. 2 tahun 1986 disebutkan beberapa syarat untuk menjadi seorang hakim, di antaranya harus bertakwa kepada Tuhan Yang Maha Esa, disamping harus berwibawa, jujur, adil, dan berkelakuan tidak tercela. ${ }^{6}$

Syarat lain bagi seorang hakim untuk menghindari kealpaan putusannya, maka seorang hakim dalam putusannya harus tahu terhadap kebebasan dirinya dari keterlibatan pihak-pihak yang berperkara. Hal ini sesuai dengan pendapat al-Mâwardî dalam I'ânah al-Thâlibîn:

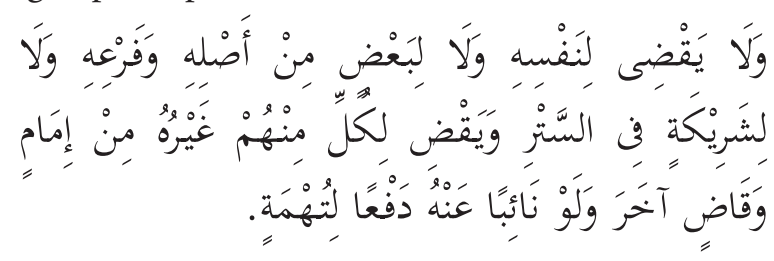

Hakim tidak boleh mengadili dirinya sendiri, orang tuanya, dan anaknya, juga tidak boleh mengadili seorang teman dagang yang pernah, melakukan sesuatu, kemudian ia bertindak untuk menutupinya. Dan yang mengadili mereka itu adalah imam dan hakim lain sebagai gantinya, untuk mencegah adanya sengketa. ${ }^{7}$

Sebagaimana dalam kitab Qalyubi wa Umairah sebagai berikut:

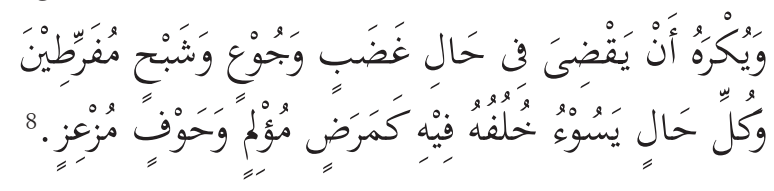

\footnotetext{
${ }^{5}$ Abdullah Sani, Hakim dan Keadilan Hukum, (Jakarta: Bulan Bintang, 1977), h. 85.

${ }^{6}$ UU No. 2 tahun 1986 tentang Peradilan Umum dan UU No. 14 tahun 1985 tentang Mahkamah Agung, (Surabaya: Sinar Wibawa, 1986), h. 8.

Al-Syayyid al-Bakrî, I'ânah al-Thâlibin, (Mesir: Dâr al-Ihyâ Isa al-Bâbi al-Halabî, t.th.) Juz IV, h. 25.

${ }^{8}$ Al-Syaykh Qalyûbî wa Umayrah, Qalyûbî wa 'Umayrah, (Mesir: Dar al-Ihyẩ Isa al-Bâbî al-ㅂalabî, 1955), Juz IV, h. 302.
} 
Hakim tidak boleh memutus suatu perkara dalam keadaan marah, sangat lapar (berlebih-lebihan), dan hal-hal yang mempengaruhi fisiknya seperti menderita sakit dan adanya kehawatiran yang mengoncangkan.

Dalam Hadis-pun Nabi menyebutkan sebagai berikut:

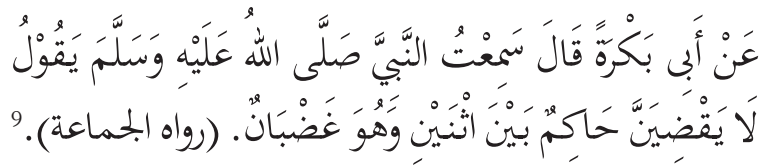

Dari Abu Bakrah mengatakan, Saya mendengar Nabi Muhammad Saw. bersabda, "Seorang hakim tidak boleh memutus persengkataan di antara dua orang dalam keadaan marah". (Hr. Al-Jama'ah)

Hal di atas menunjukkan bahwa jika hakim dalam keadaan tenang dan penuh konsentrasi maka hasil putusan yang dihasilkan akan berbeda dengan hakim yang masih terganggu pikirannya yang berakibat merugikan terdakwa, juga bertentangan dengan Keputusan Mahkamah agung No. 2 tahun1966 yaitu, tentang kode kehormatan hakim dan majlis kehormatan hakim, yaitu yang terdapat pada Pasal 3 yang berbunyi sebagai berikut: Hakim harus: (a) Tidak memihak, tegas, dan sopan; (b) Memberi tauladan yang baik. ${ }^{10}$

Kedua, faktor eksternal, faktor-faktor eksternal yang dimaksudkan dalam pembahasan ini adalah faktor-faktor dari luar pengetahuan hakim, baik itu dipengaruhi dan diperkuat oleh aparat di luar hakim, seperti pada proses perkara sebelum diajukan ke meja sidang yang diperbuat oleh jaksa, polisi, dan lainnya atau adanya pemeriksaan tersebut terdapat unsur penipuan seperti pemalsuan alatalat bukti atau saksi-saksi palsu dan lain sebagainya.

Faktor ekesternal kealpaan putusan hakim dikategorikan pada dua pokok. Pertama, faktor eksternal kealpaan putusan hakim pada proses sebelum diajukan ke meja sidang. Kedua, faktor eksternal kealpaan putusan hakim dengan adanya unsur penipuan alat-alat bukti.

Proses perkara sebelum diajukan ke meja sidang dalam hal ini adalah proses berlangsungnya penyidikan, penggeledahan, penyitaan, dan penahanan sebelum terdakwa di muka sidang. Seringkah seorang penuntut umum dan penyidik berprasangka bahwa adanya terdakwa ditafsirkan patut diduga melakukan perbuatan delik, namun demikian seharusnya penafsiran itu objektif. Jika seorang ditahan sedangkan menurut ukuran umum yang objektif tidak patut dipandang telah melakukan delik itu, maka penyidik atau penuntut umum dapat diancam pidana melanggar kemerdekaan orang, baik sengaja atau kealpaan. ${ }^{11}$

\footnotetext{
${ }^{9}$ Al-Syawkânî, Nayl al-Awthâr, h. 227.

${ }^{10}$ Abdullah Sani, Hakim dan Keadilan Hukum, h. 48.

11 Andi Hamzah, Pengantar Hukum Acara Pidana Indonesia, (Jakarta: Ghalia Indonesia, 1985), h. 60.
}

Contoh yang dikemukakan oleh Duisterwinkel ed. sebagai berikut:

Di suatu desa pada suatu hari terjadi pencurian sepeda, sebelumnya di desa itu tidak pernah terjadi hal demikian, pada hari terjadinya pencurian itu telah lewat di desa itu seorang gelandangan, yang sebelumnya telah diketahui pernah melakukan pencurian. Maka gelandangan itu patut diduga telah melakukan pencurian sepeda itu.

Menurut Duisterwinkel ed., harus dibedakan "patut diduga" (redelijk vermoeden) dengan "sangat diduga" (ernstig vermoeden). Kalau kejadian pencurian sepeda tersebut di muka dilengkapi dengan fakta-fakta atau kejadian-kejadian bahwa sewaktu gelandangan tersebut masuk ke desa itu jalan kaki, sedangkan pada waktu meninggalkan desa, ia naik sepeda, maka di sini terjadi "sangat diduga". ${ }^{12}$

Faktor eksternal lain dari kealpaan putusan hakim adalah adanya penyimpangan hak seorang tersangka sejak dimulainya pemeriksaan. Salah satu hak yang sering menimbulkan pro dan kontra dari para sarjana hukum ialah hak tersangka atau terdakwa untuk memilih, menjawab, atau tidak menjawab pertanyaan, baik oleh penyidik penuntut umum maupun oleh hakim.

Kewajiban penyidik (polisi) seperti tersebut di atas tidak penulis temukan ketentuannya dalam KUHAP. Masalah apakah tersangka berhak untuk berdiam diri tidak menjawab pertanyaan, dalam KUHAP Indonesia hanya dinyatakan dalam pasal 52 sebagai berikut:

"Dalam pemeriksaam tingkat penyidikan dan pengadilan, tersangka atau terdakwa berhak memberikan keterangan secara bebas kepada penyidik atau hakim". ${ }^{13}$

Tersangka dalam memberikan keterangan harus bebas berdasar 'kehendak' dan 'kesadaran' nuraninya. Tidak boleh dipaksa dengan cara apapun, baik penekanan fisik dengan tindakan kekerasan dan penganiayaan, maupun dengan tekanan dan paksaan batin berupa ancaman, intimidasi atau intrik baik yang datang dari pihak penyidik maupun dari pihak luar. Begitulah bunyi dari pengertian pasal 177 secara harfiah dan secara teoretis. Sedangkan bagaimana nanti dalam praktiknya, kenyataanlah yang akan berbicara. ${ }^{14}$

Di dalam Perma RI No. 1 tahun 1982 tentang Perma No. 1 tahun 1980 yang disempurnakan mengatakan dalam pasal 2, "Bahwa permohonan peninjauan kembali atas suatu putusan yang telah memperoleh kekuatan hukum tetap hanya diajukan berdasarkan alasan sebagai berikut, "Pasal 2 (a) “... pada suatu keterangan saksi atau surat-surat yang kemudian oleh hakim pidana dinyatakan palsu". ${ }^{15}$

\footnotetext{
${ }^{12}$ Andi Hamzah, Pengantar Hukum Acara Pidana Indonesia, h. 60.

${ }^{13}$ Lihat KUHAP pasal 52.

${ }^{14}$ M. Yahya Harahap, Pembahasan Permasalahan dan Penerapan KUHAP. (Jakarta: Pustaka Kartini, 1988), Jilid I, h. 136.

${ }^{15}$ Soedirjo, Perma RI. No. 1 tahun 1982 tentang Perma No. 1
} 
Seperti telah disinggung di atas bahwa perkara pidana adalah mencari kebenaran materiil, apabila hakim tidak jeli dalam memeriksa perkara yang diajukan kepadanya maka akan berakibat alpanya keputusan, hal ini merupaka faktor luar yang membuat seorang hakim alpa di dalam putusannya.

Selanjutnya dalam pasal 2 (b) dinyatakan, "Apabila setelah perkara diputus, ditemukan surat-surat bukti yang bersifat menentukan, yang pada waktu perkara diperiksa tidak ditemukan". ${ }^{16}$

Menurut hukum pidana Islam, bahwa keputusan yang disertai dengan adanya unsur-unsur penipuan dari segala segi dan bentuk apapun baik karena terdapat bukti palsu dan lainnya, lebih-lebih saksi palsu, pasti menebabkan keputusan hakim menjadi keliru.

Rasulullah Saw. bersabda:

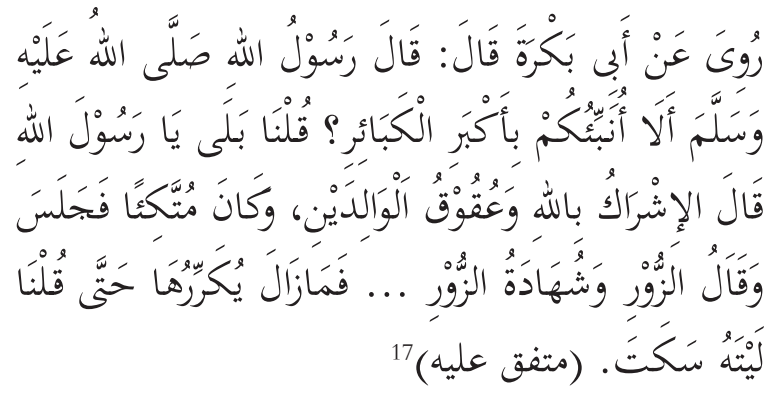

Diriwayatkan dari Abu Bakar, bahwa dia berkata, "Telah bersabda Rasulullah Saw., "Maukah aku beritahukan kepadamu yang paling besar dari dosa-dosa besar itu?" Kami berkata, "Baiklah, wahai Rasulullah". Beliau bersabda: "Mempersekutukan Allah dan durhaka kepada kedua orang tua", beliau bersandar lalu duduk dan berkata: "Ingatlah, dan perkataan dusta serta kesaksian palsu Beliau terus mengulang-ulangnya, sehingga kami berkata, "Seandainya beliau diam". (Muttafaq 'Alayh).

Begitu juga adanya kelincahan dan kepandaian dalam berbicara dari seorang tersangka, terdakwa dan seorang saksi di dalam memberikan keterangan akan berakibat tergelincirnya hakim dalam mengambil keputusan. Hal ini hendaknya betul-betul diperhatikan ketentuan serta syarat-syarat di terimanya persaksian seseorang.

Sebagaimana sabda Nabi Saw.:

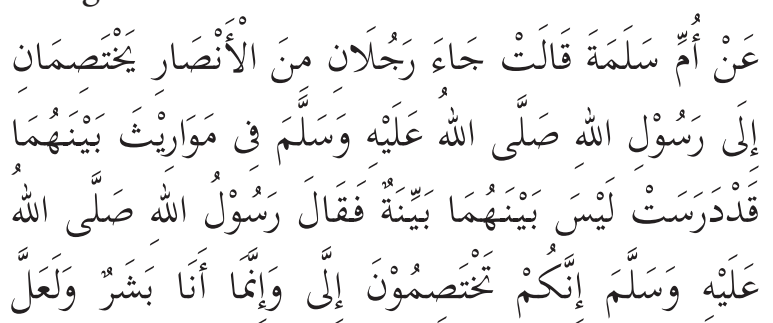

tahun 1980 yang disempurnakan pasal 2, Peninjaun Kembali dalam Perkara Pidana. (Jakarta: CV. Akademi Pressindo, 1986), h. 94.

${ }^{16}$ Soedirjo, Perma RI. No. 1 tahun 1982 tentang Perma No. 1 tahun 1980 yang disempurnakan pasal 2, Peninjaun Kembali dalam Perkara Pidana, h. 94.

${ }^{17}$ Al-San'ani, Subul al-Salam, (Bandung: Dahlan, tth.), Juz IV, h. 129.

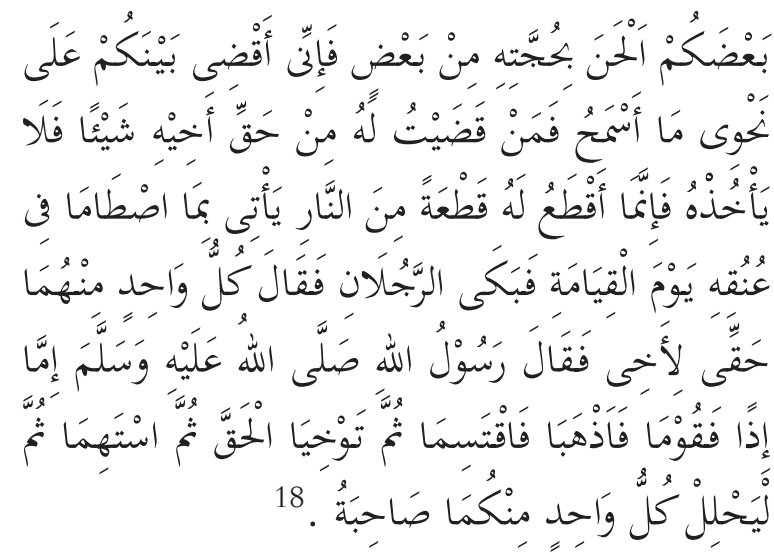

Dari Ummi Salamah, ia berkata, "Dua orang laki-laki sahabat Ansar datang kepada Nabi mempertengkarkan pusaka yang telah lama terbengkalai, tidak mempunyai keterangan yang nyata lagi. Maka Rasulullah berkata, "Sesungguhnya kamu datang mengadukan perkaramu kepadaku, sedang saya ini seorang manusia, boleh jadi sebagian kamu lebih pandai menguraikan alasannya dari yang lain, hanya saja aku ini memutuskan perkara menurut apa yang aku dengar dari keteranganketerangan yang kamu berikan, maka barangsiapa yang aku hukumkan untuknya sesuatu dari haq saudaranya janganlah mengambilnya, berarti aku telah memberikan kepadanya sepotong api neraka. Dia akan letakkan yang aku hukumkan itu di lehernya, menjadi alat penggerak api di hari kiamat." Setelah Nabi berkata demikian, kedua orang itupun menangis, masing-masing mereka berkata, "Hakku aku berikan kepada saudaraku ini". Mendengar itu Nabi bersabda, "Pulanglah ketempatmu dan bagilah harta itu sama adil di antara kamu, kemudian setelah kamu bagi sama banyaknya, berundinglah kamu serta hendaklah kamu masing-masing halal menghalalkan".

Apabila upaya pemeriksaan alat-alat bukti dan saksi masih meragukan seorang hakim dalam memutuskan perkara, maka upaya terakhir dari seorang hakim dalam mengungkapkan suatu kasus (perkara), yaitu dengan jalan seorang saksi atau terdakwa disumpah. Karena sumpah merupakan jalan terakhir seorang hakim, untuk mengungkapkan kebenaran material.

Apabila dari saksi-saksi ataupun terdakwa mengingkari apa yang telah diungkapkan oleh hakim, maka pihak yang menolak hendaklah melakukan sumpah, dan jika menolak maka penolakan sumpah berarti pengakuannya.

Rasulullah Saw. bersabda:

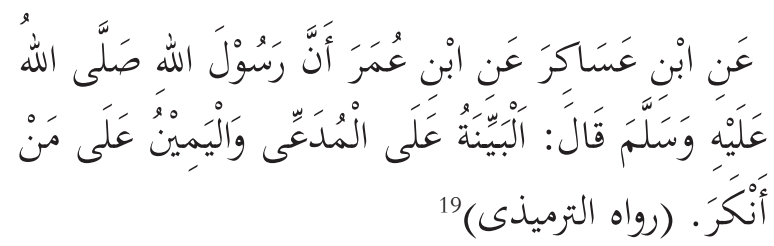

Bukti itu (wajib) atas penggugat dan sumpah itu (wajib) atas pihak yang menolak pengakuannya.

${ }^{18}$ Ahmad Ibnu Hambal, Musnad Ibnu Hambal, (Bayrut: AlMaktabah al-Islâmî, t.th.), Juz VI, h. 320.

${ }^{19}$ Al-Tirmidzî, Sunan al-Tirmidzî, (Mesir: Musthafâ al-Bâbî alHalabî, 397 H.), Juz II, h. 340. 


\section{Upaya Perbaikan Rechterlijk Dwaling}

Dalam sistim tata cara peradilan, biasanya suatu putusan yang telah memperoleh kekuatan hukum tetap tidak dapat digugat lagi. Dengan demikian ada kepastian hukum, baik mengenai perkara pidana maupun perkara perdata.

"Ne bis in idem" berarti "tidak dua kali dalam hal yang sama”. Maksudnya, bagi suatu perkara yang materi atau pokok persoalannya sudah dipecahkan dengan putusan yang berkekuatan hukum tetap, tidak terbuka lagi jalan untuk mengulangi prosesnya. Hal ini demi tegaknya kepastian hukum dan putusan hakim. Memang harus diakui tidak semua permasalahan hukum, apalagi kasus yang pelik dapat dipecahkan dengan memuaskan, baik dalam perkara pidana, perdata, ataupun perkara ketatausahaan negara.

Di dalam hukum acara pidana positif, upaya hukum untuk meluruskan kealpaan dari putusan hakim disebutkan dalam upaya hukum luar biasa, di mana jenis upaya hukum dibedakan menjadi dua golongan yaitu: upaya hukum biasa dan upaya hukum luar biasa.

Seperti yang diketahui, Undang-Undang memberi kemungkinan bagi terdakwa yang dijatuhi hukuman, menolak, atau tidak menerima putusan yang dijatuhkan pengadilan. Ketidakpuasan atas putusan tersebut, memberi kesempatan terdakwa. Pertama, berhak memanfaatkan upaya hukum biasa, berupa permintaan pemeriksaan tingkat banding kepada Pengadilan Tinggi atau permintaan pemeriksaan kasasi kepada Mahkamah Agung. Kedua, berhak memanfaatkan upaya hukum luar biasa, berupa permintaan pemeriksaan kembali atau "peninjauan kembali" putusan pengadilan yang telah memperoleh kekuatan hukum tetap. ${ }^{20}$

Di dalam hukum pidana Islam, mengenai peninjaun kembali ini, ditegaskan melalui ucapan Sayyidina Ali ibn Abi Thalib ketika diajukan kepadanya suatu perkara yang mereka sengketakan. Maka mereka tidak mau menerima putusan tersebut, dan pergilah mereka menghadap Rasulullah Saw. Merekapun menerangkan bahwa Ali Ra. telah memberikan putusan hukum kepada mereka, tetapi putusan itu tidak tepat menurut pandangan mereka. Setelah Rasulullah Saw. mendengar keterangan mereka, maka beliau pun membenarkan putusan Ali Ra. tersebut.

\section{Kemungkinan-kemungkinan Pencegahan}

Adanya kepastian hukum tidak selalu dapat menjamin tercapainya kedamaian dan keadilan. Namun

${ }^{20}$ M. Yahya Harahap, Pembahasan Permasalahan dan Penerapan KUHAP, h. 358. yang lebih penting adalah jangan sampai para pencari keadilan menjadi bingung dan kemudian dihinggapi rasa kecewa, baik dalam wujud yang nyata maupun yang tersembunyi, disebabkan oleh sikap dari para penegak hukum sendiri.

Untuk mencegah sekurang-kurangnya kemungkinan akan terjadinya kealpaan keputusan, di samping kebenaran yang nyata yang dilandasi dengan keyakinankeyakinan, ada beberapa jaminan di mana hakim sedikit sekali bisa tergelincir pada kealpaan yaitu dengan adanya openbaarheid dan pembuktian.

"Openbaarheid" yang berarti peradilan terbuka untuk umum. Disebut sebagai asas yang demokratis, oleh karena dari pasal-pasal KUHAP yang mendukung asas ini, memberi makna yang mengarah tindakan penegakan hukum di Indonesia harus dilandasi oleh jiwa "persamaan dan keterbukaan" serta penerapan sistem musyawarah dan mufakat dari majelis hakim di peradilan dalam mengambil keputusan. Dengan landasan persamaan hak dan kedudukan antara tersangka/terdakwa dengan aparat penegak hukum, ditambah dengan sifat keterbukaan , perlakuan oleh aparat penegak hukum kepada tersangka/ terdakwa, tidak ada dan tidak boleh dirahasiakan segala sesuatu yang menyangkut pemeriksaan terhadap diri tersangka/terdakwa. ${ }^{21}$

Dalam acara pemeriksaan sidang perkara seorang terdakwa, biasanya dimulai dengan pembukaan sidang oleh hakim ketua sidang, dan hakim ketua sidang harus menyatakan sidang terbuka untuk umum, pelanggaran atas ketentuan ini atau tidak dipenuhinya ketentuan ini mengakibatkan putusan pengadilan batal demi hukum, kecuali perkara yang menyangkut kesusilaan atau yang duduk sebagai terdakwa terdiri atas anak-anak. Dalam hal ini persidangan dapat dilakukan dengan pintu tertutup (KUHAP Pasal 153 ayat [3] dan [4]). Sifat terbuka dari suatu proses pidana tidak begitu terletak pada dapatnya orang masuk dalam ruangan sidang, melainkan lebih pada pemberitaan yang bebas. Pers ini adalah wakil dari persidangan terbuka itu. ${ }^{22}$

"Pembuktian" dalam hukum acara pidana, di mana hakim di dalam persidangan dan dalam menerapkan keputusan adalah mencari kebenaran materiil dan keadilan berdasarkan hukum dan Undang-Undang. Oleh karena itu sangat dibutuhkan adanya pembuktian guna meyakinkan, sehingga ia dapat menerapkan hukum secara tepat.

Menurut R. Subekti, tiada seorangpun dapat di-

${ }^{21}$ M. Yahya Harahap, Pembahasan Permasalahan dan Penerapan KUHAP, h. 57.

${ }^{22}$ Oemar Senoadji, Hukum Acara Pidana dalam Prospeksi, (Jakarta: Erlangga, 1976), Cet. II, h. 262. 
hukum, kecuali jika hakim berdasarkan alat-alat bukti yang sah, memperoleh keyakinan bahwa suatu tindak pidana telah terjadi dan bahwa terdakwa telah bersalah melakukannya. ${ }^{23}$

Dari beberapa kenyataan di atas, maka dapat disimpulkan. Pertama, untuk mempermasalahkan terdakwa diperlukan minimum pembuktian yang telah ditetapkan oleh Undang-Undang. Kedua, alat-alat bukti dan keyakinan hakim harus selalu berkaitan erat, dimana ada alat bukti yang dapat menimbulkan keyakinan hakim dan adanya keyakinan tersebut bersumber dari alat-alat bukti yang sah.

Apabila berkas-berkas kejadian bagi hakim tidak mungkin dapat mengungkapkan perkara-perkara yang diajukan sehingga menimbulkan kekaburan dan keraguraguan dalam memutuskan suatu perkara (atau had dalam hukum Islam) serta tidak bisa dijamin kecuali adanya buktibukti yang kuat dan tidak meragukan, maka keraguan dalam hal ini tentulah bertentangan dengan keyakinan yang menjadi dasar menegakkan hukum-hukum. Dengan adanya keraguan, maka tuduhan atau sangkaan menjadi tidak berarti dan tidak dipertimbangkan, karena itu adalah sumber kekeliruan. Sabda Nabi Saw.:

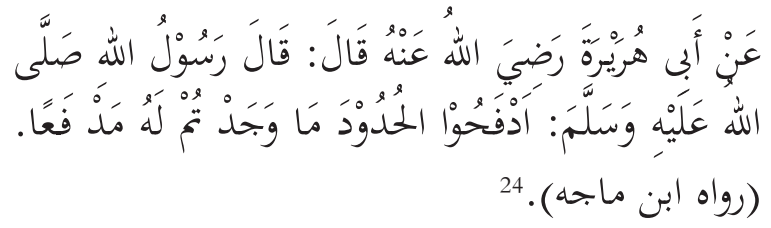

Tolaklah hukuman had selagi masih engkau jumpai jalan untuk mengelak.

Hadis tersebut menunjukkan bahwa dimungkinkan bagi seorang hakim untuk memutuskan perkara-perkara yang masih diragukan, yang nantinya akan mengarah pada putusan yang keliru, karena dengan putusan yang keliru merupakan salah satu bentuk hukuman yang menyakiti jasad atau badan seseorang, sekaligus mencemarkan nama baiknya. Sabda Nabi Saw.:

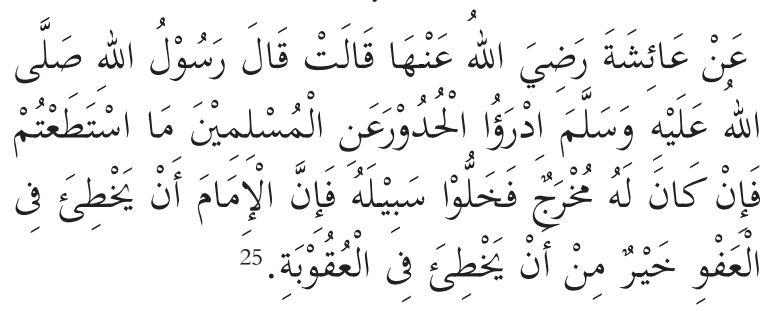

Hindarkanlah hukuman had dari kaum muslimin, selama masih mungkin, jika ada dasar untuk melepaskan seseorang dari hukuman, maka biarkanlah ia terbebaskan, seorang hakim lebih baik keliru dalam memberi ampunan daripada keliru dalam memberi hukuman.

${ }^{23}$ Subekti, Hukum Pembuktian, (Jakarta: Pradya Paramita, 1987), Cet. VIII, h. 12.

${ }^{24}$ Ibnu Majah, Sunan Ibnu Majah. (Madinah: Maktabah Al Irsyadad Hasanul Ganamul, tt).

25 Tirmidzi, Sunan At Tirmidzi, h. 438.
Di dalam hukum pidana Islam, hakim dengan segenap pengetahuan, pengalaman, serta kebijaksanaannya berusaha untuk mendamaikan para pihak yang berperkara. Namun demikian, kebijaksanaan hakim tidak diperkenankan cenderung ke arah pemaksaan terhadap pihak-pihak yang bersengketa atau terdakwa untuk menyelesaikan perkaranya. Apalagi dalam hal-hal yang berkaitan dengan hukum pidana, hak Allah lebih dominan daripada hak adam.

Dalam hal ini khalifah Umar ibn al-Khathtaab berkata:

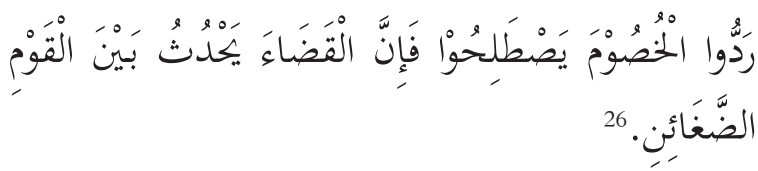

Kembalikanlah penyelesaian perkara itu kepada pihak yang bersengketa, sehingga mereka dapat mengadakan penyelesaian damai, karena sesungguhnya keputusan pengadilan itu bisa menimbulkan tidak enak di antara orang-orang yang bersengketa.

Selanjutnya khalifah Umar memberi batasan:

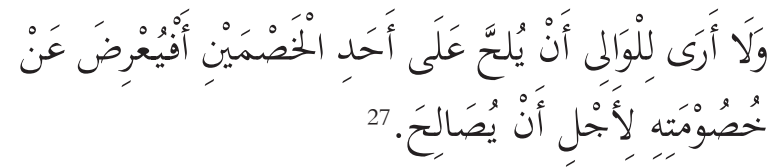

Saya tidak menyetujui hakim bertindak memaksa salah satu pihak yang berperkara atau mengabaikan permusuhan semata-mata ingin mencapai perdamaian.

Dalam kaitannya dengan hal di atas, Allah Swt. Berfirman:

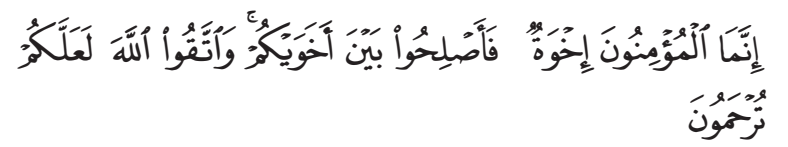

Sesungguhnya orang-orang mukmin adalah bersaudara, karena itu damaikanlah antara kedua saudaramu dan bertakwalah kepada Allah supaya kamu mandapat rahmat. (Qs. Al-Hujurât: 10).

\section{Ganti Kerugian dan Rehabilitasi}

Peninjauan kembali meskipun jarang terjadi, merupakan upaya hukum yang sangat dibutuhkan. Kekhilafan hakim yang merupakan kekurangan manusia, terjadi tidak hanya di Indonesia, tetapi di seluruh dunia, dan untuk itu dicari jalan atau cara yang harus dilalui untuk mengatasi kekhilafan itu.

Hukuman perampasan kemerdekaan yang dijalani terpidana karena kekhilafan hakim itu menimbulkan penderitaan yang sukar diperbaiki, terlebih hukuman mati yang masih dikenal dalam hukum pidana negara kita.

\footnotetext{
${ }^{26}$ Ibn Mâjah, Sunan Ibn Majah, h. 108.

${ }^{27}$ Muhammad Salam Madzkûr, Al-Qadhâ fi al-Islâm, alih bahasa: Drs. Imron AM, (Surabaya: Bina Ilmu 1979), h. 68.
} 
Tuntutan ganti kerugian yang dilakukan tersangka, terdakwa atau ahli warisnya adalah merupakan perwujudan perlindungan hak asasi dan harkat martabatnya. Yang berarti apabila seorang tersangka atau terdakwa yang mendapat perlakuan tindakan yang tidak sah atau tindakan yang tanpa alasan berdasarkan Undang-undang, memberi hak kepadanya untuk menuntut ganti kerugian. ${ }^{28}$

Pengertian ganti kerugian dan rehabilitasi disebutkan dalam Pasal 1 butir 22 dan 23 Kitab Undang-undang Hukum Acara Pidana adalah sebagai berikut:

Ganti kerugian adalah hak seseorang mendapat pemenuhan atas tuntutannya yang merupakan imbalan sejumlah uang karena ditangkap, ditahan, dituntut atau diadili tanpa alasan yang berdasarkan UndangUndang atau karena kekeliruan mengenai orangnya atau hukuman yang diterapkan menurut cara yang diatur dalan Undang-Undang ini.

Rehabilitasi adalah hak seseorang untuk mendapatkan pemulihan haknya dalam kemampuan, kedudukan, dan harkat serta martabatnya yang diberikan pada tingkat penyidikan, penuntutan atau peradilan karena ditangkap, ditahan, dituntut, ataupun diadili tanpa alasan yang berdasarkan Undang-undang atau karena kekeliruan mengenai orangnya atau hukuman yang diterapkan menurut cara yang diatur dalam Undangundang. (KUHAP Pasal 1 butir 22 dan 23).

Apa yang dijelaskan dalam Pasal 1 butir 22 memiliki kesamaan maksud dan tujuan dengan yang ada dalam Pasal 95 ayat (1) KUHAP. Perbedaannya hanya terletak pada tambahan alasan tuntutan ganti kerugian dalam Pasal 95 ayat (1). Kalau pada Pasal 1 butir 22 alasan hak menuntut ganti kerugian disebabkan karena ditangkap, ditahan, dituntut, atau diadili tanpa alasan yang berdasarkan Undang-undang atau karena kekeliruan mengenai orang atau hukuman yang diterapkan, maka pada Pasal 91 ayat (1) ditambah satu unsur alasan lagi yaitu karena tindakan lain tanpa alasan yang berdasarkan Undang-Undang.

Kalau kita perhatikan bunyi Pasal 1 butir 23 dapat dilihat bahwa tujuan dari upaya rehabilitasi tidak lain adalah sebagai sarana dan upaya untuk memulihkan kembali nama baik, kedudukan, dan martabat seseorang yang telah sempat menjalani tindakan penegakan hukum, baik berupa penangkapan, penahanan, penuntutan, atau pemeriksaan di sidang pengadilan. Padahal, semua tindakan yang dikenakan pada dirinya adalah tindakan tanpa alasan yang sah menurut Undang-undang.

Ganti kerugian atas perampasan kemerdekaan, baik berupa penahanan maupun hukuman, diatur dalam satu Ayat saja, yaitu dalam Pasal 9 ayat (1) Undang-Undang Pokok Kekuasaan Kehakiman, tidak ada ketentuan tentang ganti kerugian khusus untuk penahanan ataupun

${ }^{28}$ M. Yahya Harahap, Pembahasan Permasalahan dan Penerapan KUHAP, h. 549 khusus untuk hukuman. Hanya saja ada dua kriteria kapan tuntutan ganti kerugian itu diajukan. Pertama, tuntutan ganti kerugian yang perkaranya ada pada tingkat penyidikan atau pada tingkat penuntutan. Kedua, tuntutan ganti kerugian yang perkaranya ada pada tingkat dijatuhkannya hukuman atau tingkat menjalani hukuman.

Tuntutan ganti kerugian tentang tidak sahnya penangkapan, penahanan serta tindakan lain berdasarkan yang sah menurut Undang-undang atau karena kekeliruan mengenai orangnya atau hukum yang diterapkan dengan syarat: (1) perkaranya hanya sampai pada tingkat penyidikan; (2) atau perkaranya hanya sampai pada tingkat penuntutan seperti yang disebut pasal 138 ayat (1) KUHAP; (3) atau perkaranya tidak diajukan ke sidang pengadilan.

Terpidana yang kemudian mendapat putusan bebas atau lepas dari tuntutan pidana, karena ada peninjauan kembali (herziening) yang membatalkan putusan semula, dapat mendasarkan tuntutan ganti kerugian atas ketentuan Pasal 9 ayat (1) UUPKK tersebut. Dan jika tuntutan ganti kerugian ini didasarkan atas suatu perbuatan yang menjadi dasar dakwaan di dalam suatu pemeriksaan pidana oleh Pengadilan Negeri, menimbulkan kerugian bagi orang lain, maka hakim ketua sidang atas permintaan orang itu dapat menetapakan untuk menggabungkan perkara ganti rugi kepada perkara pidana itu. Sebagaimana disebut dalam Pasal 98 ayat (1) sebagai berikut:

Jikalau suatu perbuatan yang menjadi dasar dakwaan dalam suatu pemeriksaan perkara pidana oleh Pengadilan Negeri menimbulkan kerugian bagi orang lain, maka hakim ketua sidang atas permintaan orang itu dapat menetapkan untuk menggabungkan perkara gugatan ganti kerugia kepada perkara pidana itu. (KUHAP Pasal 98 ayat [1]).

Di dalam hukum pidana Islam, jika terjadi suatu kealpaan hakim dalam menjatuhkan putusannya, maka qâdhi atau stafnya diberi hak untuk meninjau kembali, semua putusan peradilan yang ada di bawah naungannya, serta membatalkan putusan yang dianggap tidak benar. Sebab di dalam prinsip Islam tidak boleh merugikan orang lain apalagi di dalam hal-hal yang menyangkut perkaraperkara peradilan. Rasulullah Saw. bersabda:

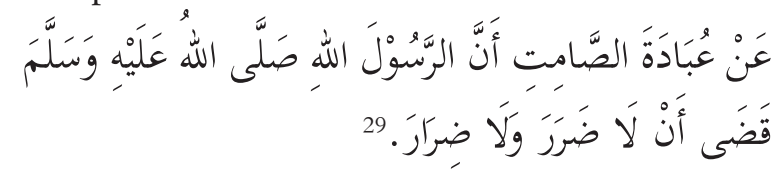

Dari Ubadah Ibn Shamit berkata, Rasulullah menghukum agar seorang tidak merugikan dan membalas dengan kerugian orang lain.

Hadis tersebut merupakan kaidah yang menjadi sumber dalam pelaksanaan hukum terkait per-

\footnotetext{
${ }^{29}$ Ibn Mâjah, Sunan Ibn Mâjah, (Madina: Maktabah Al-Irsyâd Hasan al-Ghanam al-Syayrani, t.th.), Juz II, h. 784.
} 
tanggungjawaban perkara-perkara dan penuntutan terhadap tindak-tindak pidana.

\section{Penutup}

Fikih jinayah Islam dan hukum pidana positif menentukan bahwa cara yang ditempuh dalam mengatasi rechterlijk dwaling adalah dengan mengadakan peninjauan kembali terhadap putusannya. Penyebab adanya rechterlijk dwaling dalam fikih jinayah Islam dan hukum pidana positif pada prinsipnya sama, baik dari hakim sendiri, maupun dari faktor di luar hakim. Pengaruh serta akibat hukum dari rechterlijk dwaling, baik menurut hukum positif maupun fikih jinayah Islam.

Pertama, terkait hukumnya (putusannya/vonisnya) tidak sah atau bisa dibatalkan dan tidak dapat dieksekusikan. Kedua, bagi hakim pemberi putusan, apabila disengaja, maka hakim tersebut dikenakan sanksi pemecatan serta kemungkinan pemidanaan dan mengganti kerugian, akan tetapi apabila tidak disengaja, maka negaralah yang bertanggung jawab. Ketiga, bagi terhukum berhak mendapat ganti rugi atas kerugian yang dideritanya, baik berupa siksaan, kerugian materi, maupun jatuhnya harga diri dan nama baik. []

\section{Pustaka Acuan}

Abû Dâwud, Imam al-Hâfizh Sulaymân ibn Ishââ, Sunan Abû Dâwud, Mesir: Musthafâ al-Bâbî alHalabî, 1979.

Adji, Oemar Seno, KUHAP Sekarang, Jakarta: Erlangga, 1985.

Alex, Kamus Ilmiah Populer International, Surabaya: Alfa, t.th.

Awdah, 'Abd al-Qâdir, al-Tasyrî̀ al-Jinầ̂̀ al-Islâmî,

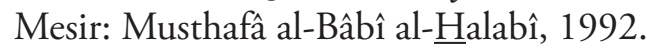

Bahansi, Ahmad Fathî, Nasri'ah al-Islâm fi al-Fiqh Jinầ al-Islâmî, alih bahasa: Drs. Usman Hasyim dan Drs. M. Ibn Rahman, Yogyakarta: Andi Ofset, 1987.

Bakrî, al-, al-Sayyid, I'ânah al-Thâlibîn, Mesir: Dâr al-

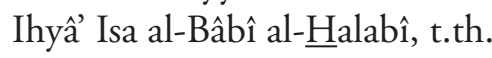

Bismar Siregar, Hukum Acara Pidana, Jakarta: Bina Cipta, 1983.

Direktorat Hukum dan Peradilan Mahkamah Agung, Himpunan Peraturan dan Perundang-undangan tentang Kekuasaan Kehakiman, Mahkamah Agung, Peradilan Umum.

Djanawi, Tahir Hadari, Bab Herziening di dalam Kitab Undang-undang Hukum Acara Pidana, Bandung: Alumni, 1982.

Haliman, Hukum Pidana Syariat Islam Menurut Ablus Sunnah, Jakarta: Bulan Bintang, 1971.

Hambal, Ahmad Ibnu, Musnad al Imam ibn Hambal, Bairut: al Maktabah al Islami, tth.
Hamzah, Andi , Kamus Hukum, Jakarta: Ghalia Indonesia, 1986. - Pengantar Hukum Acara Pidana Indonesia, Jakarta: Ghalia Indonesia, 1985.

Harahap, Hariep, Himpunan Peraturan Perundangundangan RI, Jakarta: Pradya Paramita, 1973.

Harahap, Yahya, Pembahasan Permasalahan dan Penerapan KUHAP, Jakarta: Pustaka Kartini, 1988.

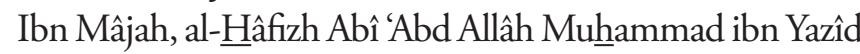
al-Qazwinî, Sunan ibn Mâjah, Madinah: Maktabah alIrsyadad Hasan al-Ghanam al-Shairanî, t.th.

Madzkûr, Muhammad Salâm, Al-Qadhâ fi al-Islâm, alih bahasa: Drs. Imron AM., Surabaya: Bina Ilmu 1979.

Mah̆masanî, Subhîî, Falsafah al-Tasyrî̀ fi al-Islâmî, alih bahasa: Ahmad Sujono, Bandung: Al Ma’arif, 1981.

Martokusumo, Sudikno, Hukum Acara Perdata Indonesia, Yogyakarta, 1973.

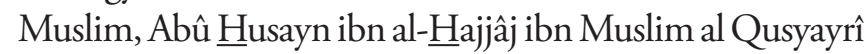
al-Naysaburî, Sahîh Muslim, Bandung: Dahlan, 1988.

Prodjohamidjoyo, Martiman, Ganti Rugi dan Rehabilitasi, Jakarta: Ghalia Indonesia, 1983.

Puspa, Yan Pramadya, Kamus Hukum, Semarang: CV. Aneka, 1998.

Qalyubi dan Umairah, Asy Syeh, Qalyubî wa Umayrah, Mesir: Dar al-Ihyâ Isa al-Bâbî al-

Saleh, Roeslan, Beberapa Catatan Sekitar Perbuatan dan Kesalahan dalam Hukum Pidana, Jakarta: Aksara Baru, 1979.

Saltout, Mahmout, Al-Islàm Aqidah wa Syarî́ah, alih bahasa: Prof. H. Bustami A. Gani dan Djohar Bahry LIS., Jakarta: Bulan Bintang, 1970.

Sani, Abdullah, Hakim dan Keadilan Hukum, Jakarta: Bulan Bintang, 1977.

Shan ânî, al-, Muhammad ibn Ismâ'îl al-Kahlanî, Subul al-Salâm, Bandung: Dahlan, t.th.

Soebekti, Hukum Pembuktian, Jakarta: Pradya Paramita, 1978.

Soedirdjo, Peninjauan Kembali dalam Perkara Pidana, Jakarta: Akademi Pressindo, 1986.

Soetomo, Hukum Kepegawaian dalam Praktek, Surabaya: Usaha Nasional, 1987.

Syâfî̀, al-, Imâm Abî 'Abd Allâh Muhammad bin Idris, Al-Um, Bayrût: Dâr al- Ma'rifah, t.th.

Syamsy al-Dîn Abî 'Abd Allâh Muhamamad ibn Abî Bakr, I'lam al-Muwaqqi în Rabb al-Alamîn, Azhariyah: Maktabah Kulliyah, 1973.

Syawkânî, al-, Muhammad ibn 'Ali ibn Muhammad, Nayl al-Awthâr, Mesir: Musthafâ al-Bâbî al-ㅂalabî, t.th.

Tirmidzî, al-, Imam al-Hââfizh Abî ‘̂̂sâ Muhammad ibn Isa ibn Sawrah, Sunan al-Turmudzî, Mesir: Musthafâ al-Bâbî al-ㅂalabî, 397 H.

Undang-undang No. 2 tahun 1986 Tentang Peradilan Umum dan Undang-undang No. 14 tabun 1985 Tentang Mahkamah Agung, Surabaya: Sinar Wijaya, 1986. 